\title{
SOCIAL PARTNERSHIP AS KEY FACTOR OF NATIONAL-PATRIOTIC EDUCATION
}

\author{
Zhanna Petrochko \\ Borys Grinchenko Kyiv University, Ukraine
}

\begin{abstract}
The problem of social partnership in the national-patriotic education is not studied enough, the strengths and weaknesses of social professionals to work together on patriotism are not disclosed. The purpose of the article: to reveal the essence and organizational and pedagogical conditions of effective social partnership in national-patriotic education on the basis of identifying the readiness of social professionals to such a partnership. The essence of the readiness of social specialists for national-patriotic education on the basis of social partnership was clarified. Such readiness is characterized by the presence of appropriate ideas, knowledge, values, skills and abilities for partnership in national-patriotic education. The list of specialists-subjects of national-patriotic education is determined. The results of the ascertaining stage of the experiment of all-Ukrainian level on the topic 'System of Training Social Sphere Specialists for National-Patriotic Education of Children and Youth based on Social Partnership' are presented. The article presents the results of the survey of 2,309 social professionals and partners in the national-patriotic education of children and youth. The organizational and pedagogical conditions for establishing partnership in national-patriotic education are determined. Emphasis is placed on the need to develop and actively implement interactive training programs for social workers on social partnership. According to the survey results, the content of such training should include such issues as: initiative and choice of partners, dialogue with them to engage in national-patriotic education, concluding agreements on effective / mutually beneficial partnership, creation and implementation of partnership projects.
\end{abstract}

Keywords: national-patriotic education, partnership, social partnership, specialists in the social sphere.

\section{Introduction}

Under contemporary conditions, social partnership is an effective means of social justice secured, social problems solved through consensus, civil peace guaranteed. It is social relations that secure an optimal balance and realization of various social groups' main interests and different subjects/social partners' efforts to achieve common goals. Social partnership envisages a number of joint actions, a search for ways of solving problems existing and new possibilities for future.

In contemporary conditions, national-patriotic education has to be the priority in the common activity of various social sphere specialists, and not just educators. The urgency of national-patriotic education under conditions in our 
country, when sovereignty and independence is of high significance, is beyond doubt. National-patriotic education is a means of renovation of national culture, social degradation prevention, a stimulus of revoking in a person of spiritual and moral qualities, a guarantee of unity and sovereignty.

At the present stage of development, national-patriotic education in Ukraine is being carried out according to the provisions of new Strategy of NationalPatriotic Education, approved by the Decree of President of Ukraine as of May 18, 2019 N 286. The strategy's aim can be achieved after different directions, the key one being constructive interaction, social partnership between subjects of national-patriotic education (Strategy of National-patriotic Education, 2019). The issue of social partnership in national-patriotic education in Ukraine has been defined as one of the standards of such activity (Petrochko, 2018).

The purpose of the article: to analyse the results of empirical study regarding readiness of social professionals to social partnership; to determine the organizational and pedagogical conditions that promote national-patriotic education on the basis of social partnership.

\section{The Problem of Research and Research Focus}

The issue of partnership interaction is studied in different countries of the world, for social partnership in the system of social relations is an index of real interest of society and the state in the further development of such relations (Carnicelli, Boluk, 2017).

We share the thought that only due to rich in content and wide intersectoral interaction, social initiatives can be innovational and consistent, which make complex tasks of social development more solvable. One sector's force cannot facilitate the process. Joint activity of partners can be secured through: innovational approaches to problems solution, development and introduction of mechanisms, thanks to which all sectors are able to contribute to common deal, new contacts provide new channels of attracting people to problems solution, partners understand better the value and qualities of every subject (Strukova et al., 2016).

The issue of forms and methods of interaction between school and local selfgovernments in the process of civic education of youth has been studied by O. Zhadko (Zhadko, 2020). At the same time, researchers Hafiri i Papathink that activity aimed at children and youth education should have family/parents as the main partner of school. The scientists underline the importance of strengthening partnership between school and family in order to improve educational process (Mara et al., 2011) and civic education (Hafiri \& Papa, 2012).

Some research is dedicated to partnership in adult education, common formation of competencies of different specialists of social sphere and to creation 
of various interactive educational programs. In part, some researchers underline that education of adults in itself favors social unity (Theodosopoulou et al., 2009).

The research mentioned above has become useful for researchers in order to understand the meaning and the essence of social partnership. At the same time, it is very important to reveal weak points of social sphere specialists' readiness to partner interaction in national-patriotic education for conditions of effective national-patriotic education based on social partnership to be secure and defined.

\section{Methodology of Research}

While this article compilation, theoretical methods (analysis, synthesis, and systematization, comparison, generalization) were used to outline the tasks of national-patriotic education in time of challenges, to define the essence of social partnership and to determine peculiarities of social sphere specialists' readiness to national-patriotic education based on social partnership.

The article represents the results of research-experimental work approved by the order of the Ministry of Education and Science of Ukraine as of April 03, 2018 N 313 "On Conducting All-Ukrainian Experiment 'System of Training Social Sphere Specialists for National-Patriotic Education of Children and Youth based on Social Partnership' in educational institutions of Zaporizhzhia oblast in 20172022" (according to the order of the Ministry of Education and Science, the author of the article - head of the project).

Within this experiment, the interviewing of social sphere specialists was conducted in October-November 2019. Other persons interested in nationalpatriotic education were involved in the interviewing.

To conduct an empirical study, the author identified three components of readiness for national-patriotic education on the basis of partnership (cognitive, motivational, practical). As follows, the indices of social sphere specialists' readiness to national-patriotic education based on social partnership are determined as follows: know ledge of the aims and principles of social partnership; inclination to work with other partners; readiness to interact with partners; ability to conduct a dialogue and to make agreements; ability to cooperate with social institutions and state bodies on national-patriotic education issues; experience in the development of own educational-methodical product used in national-patriotic education etc.

The interviewing covered 2309 persons of Zaporizhzhia. Specialists in the social sphere who had experience in national-patriotic education were involved in the survey. Among the interviewed: 1998 persons - educators (86.79\%), 235 persons - parents of students of educational establishments (10,21\%), 27 persons - representatives of state bodies (1.17\%), 24 persons - representatives of cultural institutions (1.04\%), 3 persons - military men $(0.22 \%), 1$ person - 
policeman $(0.13 \%), 9$ persons - representatives of civic organizations $(0.39 \%), 5$ persons - representatives of business $(0.30 \%), 7$ persons - representatives of other organizations-partners $(0.04 \%)$.

The interviewing was conducted in one oblast/region. It was important to find out who can be partners in national-patriotic education at the regional level, what are the difficulties and favourable factors of such a partnership. The fact is that the strategic vision, purpose and objectives of national-patriotic education is determined at the national level, and the strategy is implemented in the regions in accordance with the developed optimal models and practices of interaction of different subjects of national-patriotic education.

In order to conduct the ascertaining stage of the experiment 'System of Training Social Sphere Specialists for National-Patriotic Education of Children and Youth Based on Social Partnership', an on-line questionnaire in Google Formats has been developed. Educators and their partners in national-patriotic education of Zaporizhzhia were involved in the interviewing (according to the letter of the Department of Education and Science of Zaporizhzhia Regional State Administration as of October 01, 2019 N 02.2-16/1009).

While interviewing, resources of Oblast Scientific and Methodic Center of Monitoring Research of Education Quality of municipal establishment 'Zaporizhzhia Oblast Institute of Post-Graduation Pedagogical Education' of Zaporizhzhia regional council.

To process the results of the interviewing, methods of research and instruments were used such as: generation of reports (statistics of results after a certain question of the questionnaire) and cross-analysis (comparison of answers to a certain question).

\section{Results of Research}

Partner interaction in national-patriotic education has been defined by the author as an inter-impact of different national-patriotic education subjects, manifested in various social contacts. Thus, social partnership in nationalpatriotic education is a system of optimal interconnections and interrelations between state bodies and local self-governments, education establishments, cultural institutions and non-governmental organizations, families, and other institutions.

The author defines readiness of social sphere specialists to national-patriotic education based on social partnership as an integral quality of personality determined by notions, knowledge, values, and skills formed to a certain level and manifested in inclination to this very kind of activity and preparedness to its implementation on professional level. 
Within the frames of all-Ukrainian experiment, the subjects of nationalpatriotic education were: representatives of state management and local selfgovernments (foremost, from departments of youth policy), educators and scientists-educators, legal advisers, police, representatives of cultural institutions, civil organizations, volunteers etc.

As for Zaporizhzhia, the subjects of national-patriotic education were: Department of Education and Science; educational establishments of different types (comprehensive middle and higher education); Department of Informational Activity and Communications with Society of Regional State Administration; Department of Culture, Tourism, Nationalities and Religions of Regional State Administration; Department of Youth, Physical Education, and Sport of Regional State Administration; the branch of the Center of Probation in Zaporizhzhia; Head Department of National Police of Ukraine in Zaporizhzhia; Zaporizhzhia local center of free legal advice; Regional scientific library; Regional library for youth; libraries in educational institutions; cultural establishments; and museums; Regional Center of Patriotic Education of Youth, Regional Center of Youth; AllUkrainian Federation 'SPAS', Zaporizhzhia Regional Organization 'Union of Legal Advisers of Ukraine', Center of career 'Professionals', Zaporizhzhia regional children scout organization "Slidopyt" and many other civic organizations.

According to the results of the interviewing mentioned above, $61.31 \%$ of respondents have estimated their level of knowledge on social partnership as sufficient; $7.06 \%$ of respondents - as high one. However, $32.74 \%$ of respondents know the main aims and principles of social partnership.

The interviewed (75.88\%) admit the need of patriotic education based on partner interaction. $64.49 \%$ persons of the interviewing are satisfied with cooperation and interaction in national-patriotic education.

$21.82 \%$ of the interviewed think that the key partner in national-patriotic education of children and youth should be families (parents), $20.44 \%$ argue that the main partners are educational institutions, $14.32 \%$ consider civic organizations as the main impact in patriotic education, $12.38 \%$ - local state bodies, $11.28 \%$ - out-of-school institutions. So, the research shows that the most productive cooperation of national-patriotic education subjects is that with educational institutions. On the second place is the involving of parents in various educational measures. On the third place - civic organizations (NGOs), the fourth one - out-of-school institutions.

$21.87 \%$ of respondents know obligations of local powers and their resources in national-patriotic education, 53.83\% of persons know about it partially, $17.32 \%$ did not know about possibilities of local authorities. Almost every respondent's experience in social partnership with business structures was insufficient. 
$55.09 \%$ of respondents have wish to take part in national-patriotic measures based on social partnership. However, only $38.63 \%$ of respondents show personal initiative in the joint organization and conduct of such events.

$11.43 \%$ of respondents do not make interested and do not motivate their partners to joint activities. $27.67 \%$ are willing to organize national-patriotic events on their own. At the same time, only $18.62 \%$ of respondents admit their willingness to independently promote and practically implement a socially significant idea.

$54.61 \%$ of persons said that they use in their work on national-patriotic education interactive forms and methods. Besides, 13.99\% are experienced in development of their own methodic products on patriotic education.

Only $32.70 \%$ of respondents are ready to project activity, despite the fact that this activity has enormous potential for attracting to events of nationalpatriotic education.

It was important during the interviewing to reveal whether the interviewed could choose partners to organize events of national-patriotic education. 19.92\% of respondents declared such a skill. However, only $12.21 \%$ of respondents answered in the affirmative when asked "Do You try to find partners on Your own in order to organize work on national-patriotic education?"

$27.89 \%$ of respondents declared their skills of communication with partners on national-patriotic issues. 5.59\% of persons estimated their level of business communication with social institutions and state bodies as high. Unfortunately, only $7.28 \%$ of respondents noted that they had mastered skills of making agreements for events of national-patriotic education. The detailed results obtained are presented below.

Table 1 Results of Interviewing National-patriotic Education Subjects on Social Partnership

\begin{tabular}{|l|c|c|c|c|c|c|c|c|}
\hline \multirow{2}{*}{ Questions } & \multicolumn{6}{c|}{ Answers of the interviewed } \\
\cline { 2 - 11 } & \multicolumn{2}{|c|}{ Yes } & \multicolumn{2}{c|}{ Partially } & \multicolumn{3}{c|}{ No } & \multicolumn{2}{c|}{$\begin{array}{c}\text { Difficult to } \\
\text { say }\end{array}$} \\
\cline { 2 - 11 } & $\mathrm{N}$ & $\%$ & $\mathrm{~N}$ & $\%$ & $\mathrm{~N}$ & $\%$ & $\mathrm{~N}$ & $\%$ \\
\hline $\begin{array}{l}\text { Do You know the main aims and } \\
\text { principles of social partnership in } \\
\text { national-patriotic education? }\end{array}$ & 756 & 32.74 & 1304 & 56.47 & 137 & 5.93 & 112 & 4.85 \\
\hline $\begin{array}{l}\text { Do You consider as important } \\
\text { securing and development of social } \\
\text { and state values of Ukrainians? }\end{array}$ & 2167 & 93.85 & 109 & 4.72 & 12 & 0.52 & 21 & 0.91 \\
\hline $\begin{array}{l}\text { Do You know the authorities and } \\
\text { their possibilities in patriotic events } \\
\text { participation? }\end{array}$ & 505 & 21.87 & 1243 & 53.83 & 400 & 17.32 & 161 & 6.97 \\
\hline
\end{tabular}


SOCIETY. INTEGRATION. EDUCATION

Proceedings of the International Scientific Conference. Volume III, May $28^{\text {th }}-29^{\text {th }}$, 2021. 374-385

\begin{tabular}{|c|c|c|c|c|c|c|c|c|}
\hline $\begin{array}{l}\text { Do You consider activity on national- } \\
\text { patriotic education important? }\end{array}$ & 1752 & 75.88 & 376 & 16.28 & 51 & 2.21 & 130 & 5.63 \\
\hline $\begin{array}{l}\text { Are You satisfied with coordinated } \\
\text { cooperation with partners? }\end{array}$ & 1489 & 64.49 & 541 & 23.43 & 67 & 2.90 & 212 & 9.18 \\
\hline $\begin{array}{l}\text { Do You make interested and } \\
\text { motivated Your partners in national- } \\
\text { patriotic education events? }\end{array}$ & 978 & 42.36 & 876 & 37.94 & 264 & 11.43 & 191 & 8.27 \\
\hline $\begin{array}{l}\text { Are there interactive methods in Your } \\
\text { work? }\end{array}$ & 1261 & 54.61 & 671 & 29.06 & 262 & 11.35 & 115 & 4.98 \\
\hline Are You ready to project activity? & 755 & 32.70 & 895 & 38.76 & 336 & 14.55 & 323 & 13.99 \\
\hline $\begin{array}{l}\text { Do You take part in press- } \\
\text { conferences, master classes, business } \\
\text { negotiations, round tables, and other } \\
\text { measures to attract partners to } \\
\text { national-patriotic education? }\end{array}$ & 542 & 23.47 & 730 & 31.62 & 955 & 41.36 & 82 & 3.55 \\
\hline $\begin{array}{l}\text { Have You skills of selecting partners } \\
\text { to hold events of national-patriotic } \\
\text { education? }\end{array}$ & 460 & 19.92 & 892 & 38.63 & 729 & 31.57 & 228 & 9.87 \\
\hline $\begin{array}{l}\text { Have You skills of business } \\
\text { negotiations with partners in } \\
\text { national-patriotic education? }\end{array}$ & 644 & 27.89 & 1072 & 46.43 & 334 & 14.47 & 259 & 11.22 \\
\hline $\begin{array}{l}\text { Are you looking for partners on Your } \\
\text { own in order to organize national- } \\
\text { patriotic education? }\end{array}$ & 282 & 12.21 & 615 & 26.63 & 1251 & 54.18 & 161 & 6.97 \\
\hline $\begin{array}{l}\text { Have You skills of making } \\
\text { agreements on national-patriotic } \\
\text { education events to be held? }\end{array}$ & 168 & 7.28 & 552 & 23.91 & 1405 & 60.85 & 184 & 7.97 \\
\hline $\begin{array}{l}\text { Do You consider topical the creation } \\
\text { of a system of training social sphere } \\
\text { specialists for national-patriotic } \\
\text { education based on social partnership? }\end{array}$ & 1595 & 69.08 & 464 & 20.10 & 114 & 4.94 & 136 & 5.89 \\
\hline $\begin{array}{l}\text { Do You consider Yourself prepared to } \\
\text { national-patriotic education based on } \\
\text { social partnership? }\end{array}$ & 270 & 11.69 & 1496 & 64.78 & 240 & 10,40 & 303 & 13,13 \\
\hline
\end{tabular}

$\mathrm{N}=2309$

In general, it can be said that only $11.69 \%$ of the interviewed are fully prepared to social partnership in national-patriotic education, $64.78 \%$ are prepared partially. Nevertheless, taking into account answers of the interviewed to the previous questions, this self-estimation of readiness to social partnership in national-patriotic education can be considered subjective. 


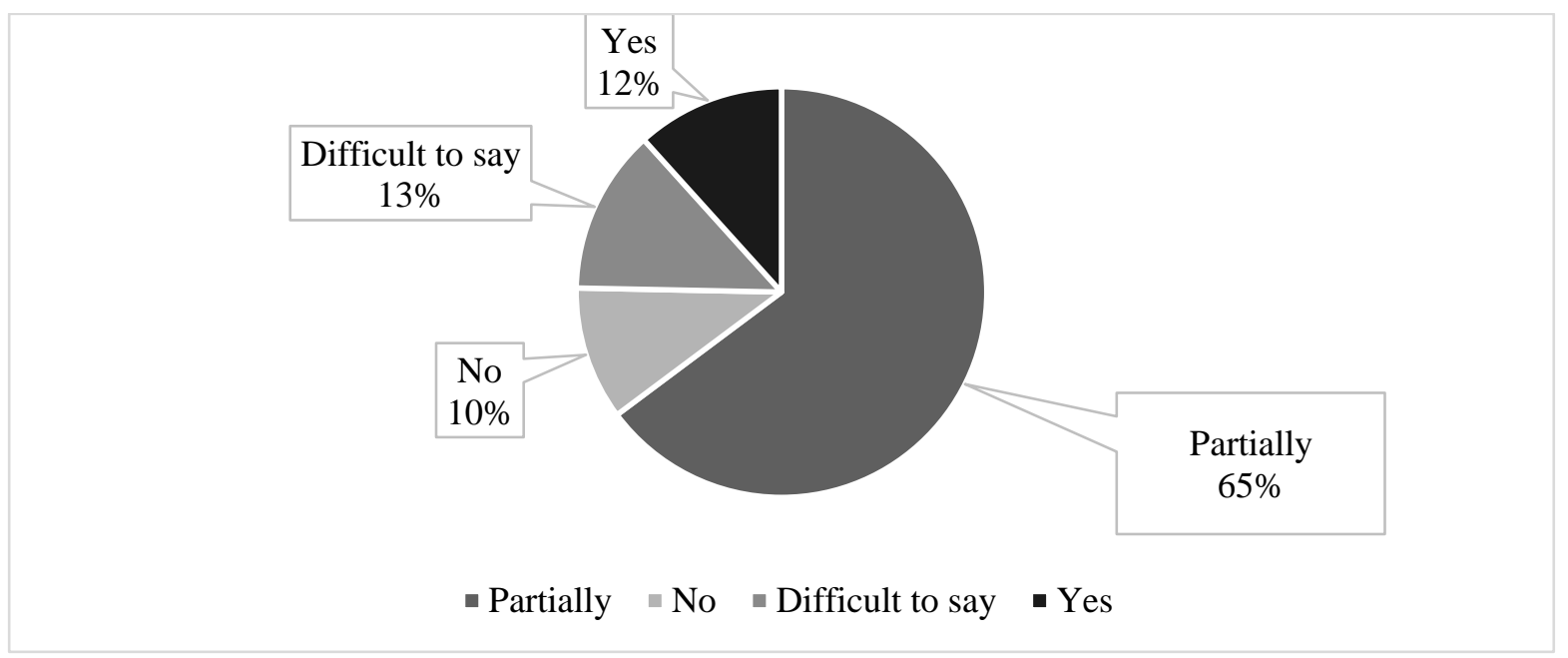

Figure 1 Respondents' Answers to the Question about Readiness to National-patriotic Education Based on Social Partnership

$69.08 \%$ consider important the creation of a system of training of social sphere specialists for national-patriotic education based on social partnership, being fully aware of weak points of partner interaction experience.

\section{Discussion}

The research results described in this article are confirmed by other research results and increase the significance of multi-vectoral study of social partnership in national-patriotic education.

Social partnership in national-patriotic education includes: interaction of representatives of institutions or organizations of different levels (state bodies and local self-governments, cultural establishments, educational institutions, civic organizations etc.), understanding by partners of their own role, responsibility and contribution in common goals, adherence to the main principles, rules, and agreements in realization of national-patriotic education tasks.

Social partnership aims at material and personnel resources to be united, methodic work perfection, pedagogical and professional qualification of various interaction subjects to improve, the best results to be presented. Social dialogue, search for compromise are the dominants of social partnership; plurality of thoughts, mutual understanding being its basis.

Research data coordinate with other scientists' view that national values formed are able to secure the unity of society and its development benchmarks (Cojocariu, 2013). Researcher L. Sokol stresses that social partnership can be implemented in the best manner when there is a socially significant common goal dictated by high values. She defines dignity as a psychological component of a social partnership model (Socol, 2019). Taking into account the facts mentioned 
above, we consider as highly important the result of the interviewing presented below: $93.85 \%$ of respondents think that Ukraine should cultivate social state values, such as sobornist, self-identity, will, dignity, and view them as the basis of national-patriotic education based on social partnership.

The article's conclusions about the importance of a partner chosen for national-patriotic education correspond to the conclusion that the strength of partnership is in attracting to interaction an optimal number of partners. L. Vyatkina and I. Gruzdeva consider the provision in the same tune: they note that task performance under social partnership covers some stages, the first one being partner organizations selection (Vyatkina \& Gruzdeva, 2016).

Some results of our research on insufficient readiness to project activity based on partnership are confirmed by the results of all-Ukrainian interviewing "Ukrainian Civic Identity". This interviewing has revealed a small part of youth from all regions of Ukraine who are experienced in national-patriotic education (17,6 \% of young people took part in city, regional or oblast projects (measures) of national-patriotic education. The part of youth that had participated in border regions was the smallest $(3,2 \%$ - in regions bordering on the Black sea and the Azov sea, 4,3\% - in regions bordering on Belorussia, 8,4\% - in regions bordering on Russia) (Ministry of Ukraine of Youth and Sport, 2018, p. 65-66). Thus, the further scientific attention should be concentrated on contemporary project activity of national-patriotic line (difficulties and peculiarities of this process), for it is democratic projects that reflect the essence of democratic consolidation (Tamayo, 2011).

Having analysed scientific sources and the results of the interviewing, the author of this article recommends organizational-educational conditions to be introduced in order to increase the effectiveness level of social partnership in national-patriotic education:

- $\quad$ building up of multi-vectoral partnership connections and creation of inter-departmental algorithms of actions for social sphere specialists in the process of national-patriotic education of children and youth,

- development and introduction of tested complex programs to train social sphere specialists in national-patriotic education, and methodic materials on organization of study and effective interaction of partners in national-patriotic education of children and youth,

- $\quad$ encouragement of using innovational educational technologies, forms and methods of partnership interaction,

- creation of resource platform for communication, informatization, experience exchange, common study.

We consider organization of training of social sphere specialists in nationalpatriotic education as a key term. The author of the article is experienced in creating and introduction of national-patriotic education programs (Bekh, 
Petrochko, \& Kyrychenko, 2017). During training sessions, subjects of nationalpatriotic education will improve their knowledge on international and home benchmarks Iguidelines of social solidarity, as well as of the essence, mechanisms and peculiarities that can be used in their practical activity; will strengthen motivation for partnership interaction of national-patriotic education in local society, will form practical skills of partnership interaction, development and implementation of common projects of national-patriotic education. The pivot of training in social partnership is defined as formation of value marks of nationalpatriotic education subjects and social and state values.

According to the aim and tasks, study on national-patriotic education can include seven sessions: 1 . Patriotism as a value and the basis for nation unity. 2. Normative and legal benchmarks of national-patriotic education of youth. 3. Analysis of resource possibilities and hindrances in introduction of nationalpatriotic education programs. 4. Intersectoral partnership in national-patriotic education. 5. Models of partnership interaction in national-patriotic education. 6. Methodic navigator of national-patriotic education. 7. Participation of youth in social life as a demonstration of patriotic position.

The proposed structure of the training program will secure a minimum sufficient level of readiness of participants to national-patriotic education based on social partnership.

\section{Conclusions and Suggestions}

Our research demonstrates that partnership in national-patriotic education is the basic term of its effectiveness. Nevertheless, partnership is now at the stage of development. Social sphere specialists are aware of its significance, are interested in partnership interaction, are socially active, they understand that partnership has to concentrate on social and state values. However, they know little about: partnership procedures, partnership principles. Social sphere specialists display little initiative, they are not ready to choose partners of national-patriotic education on their own, their knowledge of legal aspects is insufficient, they are not ready to interact with local state bodies and local self-governments, are not ready to common project activity etc.

We should create effective organizational-educational conditions and use them in their unity for efficient social partnership in national-patriotic education. A system of joint training of social sphere specialists to national-patriotic education based on social partnership is required to secure effective organizational-educational conditions. Such a system, when organized and secured as a multi-level one, will optimize the process of national-patriotic education and strengthen its efficiency. The content accents of the training, in our point of view, should be: knowledge of the potential of all partners in national- 
patriotic education, initiative in partnership, selection of partners, partner communication, making agreements on effective partnership, creation and implementation of partnership projects.

Further research of the problem of social partnership in national-patriotic education can include: research of social partnership in national-patriotic education after project, cultural-educational, and educational lines, revealing the mechanisms of mutually profitable partnership, generalization of the best regional partnership interaction models.

\section{Acknowledgement}

The author is very grateful to Natalia Bohomolova, Candidate of Pedagogical Sciences, Methodist of the Interregional Scientific and Methodological Center "Education and Civil Society" of Zaporizhzhya Regional Institute of Postgraduate Teacher Education, for help in the interviewing in Zaporizhzhia (Ukraine).

\section{References}

Bekh, I. D., Petrochko, Zh.V., Kyrychenko, V.I. (2017). Treninh z patriotychnoho vykhovannia. Osvita ta rozvytok obdarovanoi osobystosti, 7-8, 61-65. Retrieved from: http://otr.iod.gov.ua/images/pdf/2017/7-8/14.pdf.

Carnicelli, S.C. \& Boluk, K. (2017). The promotion of social justice: Service learning for transformative education. Journal of Hospitality, Leisure, Sport \& Tourism Education, 21 (B), November 2017, 126-134.

Cojocariu, V.M. (2013). Petre Tutea or some axiological anchors for a necessary patriotic education. 5th International Conference EDU-WORLD 2012 - Education Facing Contemporary World Issues. Procedia - Socialand Behavioral Sciences, 76, 204-208.

Hafizi, A. \& Papa, M. (2012). Improving the quality of education by strengthening the cooperation between schools and families. Problems of education in the 21st century, 42, 38-49.

Mara, D., Mara, E.L., Andrei, O., Danciu, E.L. (2011). The Role of School-Family Partnership in the Implementation of Inclusive Education in Romania. The New Education Review. 26 (4), 228-237.

Petrochko, Zh. (2018). National and Patriotic Educationof Childrenand Youth: Questions of Standards and Indicators. Education Modern Discourses. The National Academy of Educational Sciences of Ukraine, 1, 200-207. doi:10.32405/2617-3107-2018-1-20

Results of expertise-analiticr esearch on formation of standards of national-patriotic education and defining efficiency indices of national patriotic education indices. (2018). Ministerstvo Ukrainy u spravakh molodi ta sportu. Retrieved from http://dsmsu.gov.ua/index/ua/material/36386

Sokol, L. (2019). Гідність як психологічна складова моделі соціального партнерства. Scientific journal of the National Pedagogical University named after MP Drahomanov. Series 12: Psychological Sciences, 8 (53), 76-85. Retrieved from http://enpuir.npu.edu.ua/handle/123456789/28058. 
Strategy of National-patriotic Education. (2019). Decree of the President of Ukraine of May 18, 2019 № 286/2019. Retrieved from https://zakon.rada.gov.ua/laws/show/286/2019

Strukova, M.N., Yashin, A.A., Strukova, L.V. (2016). Социальное партнерство и устойчивое развитие общества. Social partnership and sustainable development of society. Materials of the International scientific-practical conference (Yekaterinburg, February 16-17, 2016), 137-143. Retrieved from: http://elar.urfu.ru/handle/10995/38027

Tamayo, A.L.G. (2011). Citizen formation from the pedagogical potential of the studies of the territory. Problems of educationin the 21st century, 27, 67-74.

Theodosopoulou, M., Siassiakos, K., Heodosopoulou, V. (2009). Greek adult education moving forward in the knowledge society. Problems of educationin the 21st century, 15, 163-168.

Vyatkina, L.B., \& Gruzdeva I.V. (2016). Social partnership as a factor in the success of an education alorganization. International Research Journal, 11 (53), 29-31. DOI.: 10.18454/IRG.2016.53.235.

Zhadko, O. (2020). Forms and methods of interaction between schools and local governments in the process of civic education of students. Educational Discourse, 1 (28), 31-43. DOI: 10.28925/2312-5829.2020.1.3 